Badaru, K. A. \& Adu, E. O., The Political Awareness and Participation

of University Students in post-Apartheid South Africa

\title{
The Political Awareness and Participation of University Students in post-Apartheid South Africa
}

\author{
Kazeem Ajasa Badaru ${ }^{* 1}$ and Emmanuel Olusola Adu ${ }^{1}$ \\ 1. University of Fort Hare, South Africa \\ *Corresponding Author: kbadaru@ufh.ac.za \\ Received : 2021-04-05 \\ Revised : 2021-05-24 \\ Accepted : 2021-07-11 \\ $10.46303 /$ ressat.2021.22
}

How to cite this paper: Badaru, K. A. \& Adu, E. O. (2021). The Political Awareness and Participation of University Students in post-Apartheid South Africa. Research in Social Sciences and Technology, 6(3), 1-24. https://doi.org/10.46303/ressat.2021.22

This is an Open Access article distributed under the terms of the Creative Commons Attribution 4.0 International license (https://creativecommons.org/licenses/by/4.0/).

\begin{abstract}
Being politically aware and participating in politics are essential determinants of a society's democratic survival. One source of concerns for researchers of political behavior regarding post-apartheid South Africa is the low rates of youth's political participation. There is however a dearth of empirical studies in the extant literature on the university students' political awareness and their political participation in post-apartheid South Africa. This mixed-methods research was conducted to fill in this obvious gap. A study sample of 372 undergraduate students selected from one rural university in the Eastern Cape through the stratified random sampling techniques yielded the quantitative data, and the qualitative data were obtained from five (5) executive members of the Student Representative Council (SRC) who were purposively selected for semi-structured interviews. Both quantitative and qualitative data analyses were performed by employing simple descriptive and Pearson correlation statistics as well as a thematic content analytical approach. Results showed that nearly all the respondents demonstrated a high level of political awareness in terms of rights to vote and be voted for (99.4\%), the importance of parliament, and the national constitution (99.1\%) while the respondents' levels of political participation appeared to be below average as only (49.2\%) voted during the 2017 SRC election, whereas (30.4\%) of them voted in the 2014 national elections. Students' political awareness was found to be significantly correlated with their participation in political activities on-campus $(r=0.130)$ and off-campus $(r=0.185)$. In conclusion, the bivariate analysis indicated that there was a positive correlation between students' political awareness and their participation in politics $(P<0.001)$.
\end{abstract}

Keywords: University students, Political awareness, Student Representative Council, Political participation; post-apartheid South Africa. 
Badaru, K. A. \& Adu, E. O., The Political Awareness and Participation of University Students in post-Apartheid South Africa

\section{Introduction}

Researches have shown that political awareness is associated with citizens' participation in political activities (Kuotsu, 2016; Sarwar et al., 2021; Kholisoh et al., 2019). This study, conducted between 2017 and 2018, is another empirical contribution to the debates and efforts at mitigating the paucity of political participation of youth globally and specifically in the post-apartheid South African context. Previously, Badaru and Adu (2020) have established the connection between university students' use of media [for raising political awareness] and political participation in South Africa. It is of interest to extend further the discourses on university student political participation by investigating how their levels of political awareness could hitherto or otherwise propel their participation in political activities. Nonetheless, the expression of concerns and apprehensions arising from the low participation of South African youth in political activities (Badaru \& Adu, 2020) was the impetus and rationale for this particular study.

Political awareness is significantly imperative for a democratic society to be built on accountability, transparency, and good governance. Every democracy, therefore, needs citizens' participation to ensure its further development and survival. Politically aware citizens help in sustaining democracy by being critical of the government's actions, inactions, programs, and policies. Ahmed et al. (2015) argued that politically aware citizens should be able to hold their government and other public servants accountable for manners in which the country's affairs are being managed. Political awareness has been considered as a function of three constituents namely; the level of exposure to political information, the intellectual capability to retain and organize political information, and the desire to acquire and understand the political news. In other words, political awareness implies having access to political information, political participation, media primarily in terms of political contents that stimulate interest in politics and public affairs (Kuotsu, 2016).

The word awareness is originally Latin, which means to know things on an ongoing basis. Francis Bacon first used the word in the year 1600. It was also used in John Locke's Philosophical Disputes. The term awareness has been interpreted to imply those ideas that pass in the human mind, and the early 19th century, and psychology, it has emerged into existence, which was identified as the science of consciousness. Therefore, this term was used to mean all the sensations and mental images, thoughts, desires, and emotions. Political awareness results from the social development engendered by the human need to prepare the tools for interaction with nature in such a way that man was able to distinguish between what is essential and non-essential and demonstrate causes of the phenomena, being aware of the relationship with the environment (Althubetat \& Jarrar, 2013). Political awareness is helpful to an individual in analyzing political reality away from emotional perceptions. Citizens who are politically aware will see issues differently and perhaps in the national interest devoid of sentiments in whatever forms.

The notion of political participation consists of numerous types of political engagements such as voting in an election, involvement in activities of the political parties, other voluntary organizations, conversations concerning politics, and protests against constituted authorities. The debates on the notion of political participation in the literature indicate that it is practically 
Badaru, K. A. \& Adu, E. O., The Political Awareness and Participation of University Students in post-Apartheid South Africa

impossible to divorce democracy from political participation (Van Deth, 2001). The latter is very germane to the good continuation and survival of the former (Gutmann, 1987, as cited in Badaru \& Adu, 2020). According to Miller (1992), democracy aims at aggregating the preferences, desires, and needs of the individual citizens into a collective whole. Seyla Benhabib (as cited in Frateschi, 2016) describes democracy as the model for organizing public interest and exercise of power in the democratic institutions informed by principles guiding the process of decision-making arising from a democratic deliberation among citizens considered to be politically equal. For democracy to thrive, citizens have to participate in the political system which to a large extent can be influenced by their level of political awareness. According to Verba and Nie (1972), this is important because democracy is only little in a state where a few individuals are involved in the decision-making; while there is more democracy in a country where more people participate in the decision-making processes.

Political participation involves all the activities that the citizens engage in to influence the decisions and policies made by the government and its officials. It is a democratic engagement through which the citizens have the benefits of communicating their dissatisfactions, demands, and preferences to their elected representatives and other government officials and may continue to mount pressure on them until they respond positively to their yearnings (Teorell, 2006). It is concerned with the citizens' activities aimed at influencing government's decisions and policies through voting in an election, meeting and consulting with party leaders and government officials and elected representatives, and declaring protests, strikes, and demonstrations against the erring leaders (Resnick \& Thurlow, 2015). In an attempt to theorize the concept of political participation, various scholars have considered its meaning from the normative perspectives in terms of three distinctive but intertwined models. The responsive model theorists have argued that political participation is a form of democratic action intended to influence the decisions of those who have a say in government. The proponents of the participatory model insist that political participation is an attempt made by private citizens to have a say in the decisions and policies of the government. The deliberative model theorists believe that political participation is one way by which the citizens find out what to say about the government's actions and inactions as well as other political issues that may directly or indirectly affect their well-being (Teorell, 2006).

The contribution of political awareness towards active participation in political processes cannot be downplayed. Citizens' understanding of politics and other politically related issues is shaped and developed by their exposure to political information especially through the media. The level of political participation of individuals is dependent on their level of political awareness. Kuotsu (2016) posits that individual citizens must have some level of awareness not only about democratic processes and institutions of governance but also about certain political issues both at the national and international levels. We are of the view that individuals, whose level of political awareness is low, may be uninterested in participating in all forms of political activities. Pericles argues that a citizen should not feel unconcerned about the political affairs of his state just because he is capable of taking care of his family; such an individual who chooses not to participate in public affairs should not be regarded as a harmless but a useless citizen (Van Deth, 2001, p.3). By implication, every responsible citizen must have some understanding of politics and also participate in the political activities of his country. As 
Badaru, K. A. \& Adu, E. O., The Political Awareness and Participation of University Students in post-Apartheid South Africa

Minogue put it, "The thing called 'apathy' is democracy's version of original sin" (as cited in Van Deth, 2001, p.3). For anyone to be politically aware, he can never be guilty of a common crime otherwise known as apathy. This underscores the signification of political awareness for effective participation in a democracy. For the purpose of this study, political participation of university students implies participating in political activities that occur on-campus as well as off-campus. In South Africa, university students are enjoined to join any student political and social organizations existing on campus and also as registered students automatically become members of the Student Representative Council (SRC) whose operational structure and constitution are modelled after the parliamentary-presidential system of democracy at the national and provincial levels. Another interestingness about student political organisations in South Africa's higher institutions is that some of them are the youth-wings of constitutionally recognized national political parties. For instance, we have the Democratic Alliance Student Organization (DASO) and the African National Congress Youth League (ANCYL) as the institutional campus branches of the national parties; the Democratic Alliance (DA) and African National Congress (ANC) respectively. These institutional campus branches receive supports in terms of funding and donations usually during the SRC electioneering campaigns to ensure victory for their candidates.

Political participation is an important democratic exercise that makes it possible for citizens' voices to be heard in the corridors of power. It is regarded as 'one of the cornerstones of any democratic society' (Castillo et al. 2015, p.16). The involvement of citizens in the democratic governance of their country would make the political leaders have a sense of responsibility and also become accountable. Political participation enables the government to understand its citizens' needs and aspirations while the active involvement of citizens in partisan politics compels the government to fulfil its constitutional role. Why should university students then participate in political activities? It is one of the surest methods for students to become involved in the making of positive changes and contributions in their particular community and the society as a whole. Students' engagement with political activities would give them an understanding of how a government works and what role it has to play in solving the socioeconomic and political problems confronting their country. Students' participation in politics, therefore, would help in bringing the government's attention to addressing fundamental problems that need to be solved in such a way that the impact of governance becomes positive and visible.

Political awareness is, therefore, very crucial for students to become interested in political processes both on campus and at the national levels. It would be helpful for them also to become well informed about politics, and to be able to make informed decisions when it comes to elections and selection of candidates, and joining of political parties. The media and more importantly the digital technologies have become very instrumental in raising students' awareness about political affairs and increasing their participation in political activities (Anwar \& Jan, 2010). Social media, for instance, have made students susceptible to political awareness and online participation in politics practically made possible by the internet and access to mobile phone technologies. Such that, those students who were previously uninterested in politics now have to join in debates and conversations with friends, families, and their teachers across space and time on politically related issues. 
Badaru, K. A. \& Adu, E. O., The Political Awareness and Participation of University Students in post-Apartheid South Africa

Gutmann's advocacy is instructive when he argues that students should be given opportunities to take part in the formulation of policies and decisions that would impact their affairs to build in their self-efficacy and encourage them to participate in their country's political activities actively (as cited in Badaru \& Adu, 2020). The university students, being among the youth, have more access to government information through various media platforms. Expectedly, they are supposed to engage in political discussion and other politically-related activities both within and outside the university campus. In South Africa, university students have been known for their participation in campus politics on the platforms of the various political organizations affiliated with the national political parties. Amoateng's study (2015), conducted at the University of Johannesburg, affirmed that students demonstrated a high level of political awareness which positively influenced their participation in the political processes. In other words, there is an indication suggesting that levels of political awareness have a positive relationship with the levels of participation in political activities.

The motivation for conducting this particular study was borne out of the dearth of empirical studies in the extant literature on the university students' political awareness and their participation in politics, specifically in the Eastern Cape Province, South Africa. This study, therefore, investigated the university students' political awareness and political participation in post-apartheid South Africa to fill in the gap in the body of literature. The researchers selected one university in the Eastern Cape as the study location. The choice of this university was informed by the fact that it was one of the historically black universities where political struggles, protests, and unrelenting movements were launched against the former apartheid regime before the eventual enthronement of the democratic government in 1994 in South Africa. The paper's focus includes the theoretical framework, literature review, objectives of the study, research methods and procedures, results analysis, discussion of findings, and the study's implications.

\section{Statement of the Problem}

The underlying essence of democracy is citizen participation and South Africa being one cannot be an exception. There has to be a decline in political participation when political awareness is poor among the citizenry. It is assumed that the political apathy among students, or youth in general, today might be as a result of their little or poor levels of political awareness. Such a political trend as observed among post-apartheid South African youth is dangerous for the country's nascent democracy. Plato's thought on one of the outcomes of political apathy is very instructive here as he remarked, thus: "the price of apathy towards public affairs is to be ruled by evil men" (as cited in Sasikala \& Francisca 2017, p.78). Our observations about university students in South Africa show that they are vibrant and articulate in terms of staging demonstrations and strikes against administrative decisions of their universities as well as government decisions that are perceived to be unjust and unfavorable to their plights and academic needs on campus. More importantly, many of them are registered members of one student political organization or the other; thereby participate in various forms of politicking at the level of the campus. There is nonetheless a need to investigate the students' level of political awareness, their participation in politics and to determine whether or not there is a correlation between their political awareness and participation. 
Badaru, K. A. \& Adu, E. O., The Political Awareness and Participation of University Students in post-Apartheid South Africa

\section{Research Questions}

The following research questions were answered in this study:

- To what extent are university students politically aware in post-apartheid South Africa?

- In what ways have students participated in politics on and off-campus?

- To what extent is students' political awareness associated with their participation in politics?

\section{Theoretical Framework and Literature review}

This study has been grounded in the cognitive mobilization theory of civic literacy and participation as espoused by Dalton (Amechi, Innocent, and Ikechukwu, 2018). The argument is suitable for this study because it provides some theoretical explanation for political awareness and participation in politics. Besides, this theory is relatively known in the literature in terms of its use to advance arguments for political awareness and involvement in politics. The cognitive mobilization theory of civic literacy and participation argues that civic literacy determines an individual's levels of political knowledge and political participation. It is believed that individuals become empowered by political education through what they learn about political issues. They, therefore, mobilize their cognitive knowledge of politics to participate in various political activities. Conversely, individuals without sufficient civic education tend to exhibit political awareness that is poor or low, about the political processes, whereas those having sufficient political knowledge of political objects (democracy, party system, candidates, institutions of the state etc.) have better inclinations to engage actively and participate in all forms of political activities (Amechi et al., 2018).

\section{Students' Political Awareness}

Students, like other citizens, need to understand the political systems of their country and the world around them. This is important for them to be able to make informed decisions when the need arises to elect their leaders and political representatives. Kuotsu (2016) avers that political awareness plays a critical role in providing explanations for the variation in political participation. He submits further that a higher level of political awareness would certainly lead to a greater increase in participation. It is therefore important for university students to have an awareness of democratic institutions, their rights, and their duties as responsible citizens. In another study conducted by Althubetat and Jarrar (2013), it was found that students of the University of Petra who offered any political science course as an elective exhibited a high degree of political awareness. This is a clear indication that exposure to knowledge of politics can greatly increase the students' political awareness. Furthermore, in a study conducted by Sharma and Choudhary (2014), results showed that there was no significant difference in political awareness among male and female secondary school students. From another perspective, institutions of learning have been regarded as an important role player in raising political awareness of persons through various pedagogical approaches, social and academic programs integrated as part of curricula, lectures, conferences, and training towards the preparation of individuals to take up responsibilities for public affairs and fulfillment of civic duties (Alsati and Al-Ghanem, 2017). 
Badaru, K. A. \& Adu, E. O., The Political Awareness and Participation of University Students in post-Apartheid South Africa

\section{Students' Political Participation}

Much concern has been raised in the literature about the low rates of youth participation in formal and informal political activities such as voting during elections and involvement in party politics (Robertson, 2009). Blais and Rubenson (2013, as cited in Castillo et al. 2015) have argued that the lower rates of young people's political participation these days have become sources of worry and appeared as a worldwide phenomenon. In Eastern Europe, research suggests that young people are least likely to participate in voting exercises and activities of the political parties (Fieldhouse et al., 2007). In South Africa, reports indicate that university students have participated in voting and other electoral activities during the national election elections in 2005 and 2014 respectively (Luescher-Mamashela, Luescher, and Kiiru 2011; Mhlomi and Osunkunle 2017). A vast majority of students (76\%) who participated in Mhlomi and Osunkunle's study (2017) confirmed that they participated and voted in South Africa's 2014 national election. According to Luescher-Mamashela et al. (2011), surveyed students from African universities (South Africa [62\%], Tanzania [62\%], and Kenya [79\%]) confirmed their participation in national elections of their respective countries between 2005 and 2007.

We have observed also that not all university students are keenly interested in participating in political activities whether on-campus or off-campus. Some of them are only interested in the souvenirs such as the T-shirts, face caps, and other materials provided to them by the various political organizations operating on campus while others are more interested in the real politicking that such political organizations provide as an opportunity to test their political skills. A democratic body through which students in universities and other higher education institutions get represented in the scheme of governance on campus is known as the Student Union or Student Representative Council (SRC). Adelabu and Akinsolu (2009) and Rou et al. (2017) agree that the SRC provides the platform as the first political organization where students of higher institutions practice political functions and actively participate in political activities. South Africa makes a provision for the inclusion of the SRCs in its higher education policy to promote cooperative governance philosophy among stakeholders in the nation's postapartheid higher education and training (Klemenčič et al., 2016).

The SRCs in the 1980s were considered as subalternate to the student political organizations that operated in South Africa's public institutions of higher learning (Moreku, 2014). However, this status of subordination has changed these days as SRCs are now actively involved in the protection of rights and welfare interests of the student organizations. According to the Higher Education Act 101 (1997), SRCs are to statutorily participate as critical stakeholders representing the student bodies in the affairs of public higher education institutions existing in South Africa. By and large, the SRCs serve as the students' mouthpiece as they are playing an active role in the university's decision-making meetings at the faculty, senate, and council levels. They are also responsible for procuring resources, organizing social and academic activities, and distributing released funds from the university management to all registered societies, clubs, and organizations to which students belong on campuses (Cele \& Koen, as cited in Moreku, 2014). The SRCs in post-Apartheid South Africa are creations of the law operating a constitutional structure for student representation. They run and conduct elections based on democratic principles and their elected representatives in the executive and parliamentary positions hold offices for a one-year tenure subject to renewal provided representatives are 
Badaru, K. A. \& Adu, E. O., The Political Awareness and Participation of University Students in post-Apartheid South Africa

not due for graduation from the universities in the next academic year. Student participation in SRC activities is enshrined in its constitution structured in tune with the dictates and electoral regulations of South Africa's constitution which provides for political participation of political parties and candidates or political gladiators (Klemenčič et al., 2016).

From another perspective, Nyundu et al. (2015) and Lake (2010) investigated factors that propelled and inhibited the interests and participation of students in the SRC politics at the campus level. One factor, according to these scholars, is the success stories of key political figures around them and beyond. So, they feel encouraged to follow in the footsteps of successful and prominent politicians. Students who have ambitions and persuasions to align with the social and political programs for them to have a sense of belonging is another factor propelling their interests in politics at the campus level. On the contrary, there are other students who choose to be politically apathetic because their perception is poor about student leaders. They are also afraid of losing their studentship, scholarship or funding opportunities, employment offers, and anti-democratic dispositions of university authorities that stifle freedom of expression and political participation (Nyundu et al., 2015; Lake 2010). In a report published by Dibetle (2007, 14 June), the political apathy of students at the University of Pretoria (UP), South Africa was revealed. This report indicated that the UP'S SRC election witnessed a low turnout. Out of 22,000 eligible voters, only 2500 (11.4\%) of them turned up to vote. This is the extent of concerns that forms the justification for this present study.

\section{Relationship between Political Awareness and Participation in Politics: Empirical Studies}

A very recent descriptive study investigated Al-Ain University students' level of political awareness and the university's role in raising students' political awareness (Al-Khaza'leh \& Lahiani, 2021). This study was a mixed-research design involving 980 students. Its findings showed that the university students demonstrated a high level of political awareness. Interestingly, it found also that students from the faculty of humanities were better politically aware than their peers from other faculties. Male students were said to be more politically aware than their female counterparts and the university was found to be critical in the development of students' level of political awareness. In another more recent study, Sarwar, Ramazan and Shafiq (2021) explored how political talk shows on television impacted students' political awareness and political participation in Pakistan. It was a cross-sectional study of 400 students selected through the multistage sampling technique from twelve universities. The study's findings affirmed that political awareness was associated with political participation. Kholisoh et al. (2019) were interested in determining the new media influence on the millennial generation's political awareness as well as their participation in political activities in the Special Capital Province of Jakarta. They utilized the quantitative method to sample 400 young people aged between 17 and 37 years. Their findings affirmed that new media's political information had both direct and indirect influences on the young people's political awareness as well as their participation in various political activities.

Kuotsu's study (2016) on political awareness and its impact on political participation was carried out to find whether or not their level of political awareness influenced the respondents' (aged 18 years and above) political participation. This study was a mixed design with a sample size of 402 participants selected from the rural and urban districts of Nagaland in India. The author 
Badaru, K. A. \& Adu, E. O., The Political Awareness and Participation of University Students in post-Apartheid South Africa

found that there was a relationship between political awareness and participation in electoral activities among the respondents. It was also found that mass media exposure was a determinant factor influencing citizens' political interest and participation in all forms of political activities.

In another study conducted by Ahmed et al. (2015) the authors set out to determine the level of political awareness among students in a public university of Pakistan. It was a survey design consisting of a sample of 200 students drawn from selected departments in the Social Sciences and the Natural Sciences. This study found that students generally exhibited a reduced level of political awareness. It also found that the Social Sciences' students demonstrated a better level of political awareness than their counterparts in the Natural Sciences. Amoateng's study (2015) was a qualitative design and interviews were conducted with 1,214 undergraduates of the University of Johannesburg in South Africa. The study found that parents' political socialization and participation are important determinants of the students' political participation. It was also found that the students exhibited a high level of political awareness which was positively correlated with their participation in political activities.

In Nairobi, Ndiritu's study (2007) investigated the critical role of television debate programs in the creation of political awareness among the young Kenyans. The author asserted that the youth's political participation had become a source of concern to leaders of thought and political stakeholders in the country. Using the purposive and snowballing methods of data collection the author found that political television programs had an enormous impact on the political awareness of the youth. The study affirmed that the youth had benefited immensely from the television political discussions increasing their understanding of the political processes. It was concluded that the television political discussions positively contributed to fostering and raising the youth's political awareness; activating their interest in politics, and motivating them to participate in the political processes.

Similarly, one study conducted at the University of Karachi, Pakistan by Yaseen et al. (2018) examined the essential role of political talk programs through television and radio in fostering political awareness among university students. The study was a quantitative design, and 196 participants were randomly drawn from two different faculties namely the faculty of the Social Science and Humanities as well as the faculty of sciences. The study found that political talk shows were significantly correlated with the participant's level of political awareness. The study further showed that political awareness was capable of encouraging political knowledge and discussion of political issues which hitherto would lead to increased political participation among the university students.

A case study of students at the University of Gujrat, Pakistan contributed to research on the mass media influence and political awareness concerning the participation of youth in politics (Ali et al., 2013). This study found that the print and electronic media through their viewership and readership exerted influence on the youngsters' political awareness, how they judge political issues, their interest, and participation in politics. It further confirmed other studies that television was most influential in the dissemination of political information and the creation of political awareness among university students. 
Badaru, K. A. \& Adu, E. O., The Political Awareness and Participation of University Students in post-Apartheid South Africa

\section{Method}

This study was a mixed-methods design (concurrent triangulation) conducted at one selected university in the Province of the Eastern Cape, South Africa between 2017 and 2018. The university was chosen because it was one of the historically black universities that led the struggle against the apartheid regime and for the enthronement of democracy in South Africa. By a mixed-methods design, we collected and analyzed both quantitative (survey) and qualitative (semi-structured interview) data concurrently but separately to see where there was any similarity or difference in the results.

\section{Participants}

The participants for this study were selected by using probability random and purposive sampling techniques which were referred to as the judgement sampling by Etikan, Musa and Alkassim (2016). For the quantitative strand of the study, a sample of 375 undergraduates were randomly selected while another sample of 5 members of the SRC executive were purposively interviewed for the qualitative strand. The belief was that SRC members were actively involved in both on-campus and off-campus politics. Table 1 below has details of the qualitative study's participants. The sample size of 375 was determined at the confidence level of 95\% from the population of 14,408 students via the online Creative Research Survey Software.

For the quantitative strand as shown in Table 1,60.5\% of the participants were male, and the remaining $39.5 \%$ were female. The participants' ages were between 16 and 31 years. A majority of them (41.0\%) fell within the age bracket (21-25) years. Most of the participants (36.3\%) were from the departments in the Faculty of Sciences; $21.5 \%$ of them were from the Department of Political Science, and Public Administration; 8.3\% of them were from Law faculty, and surprisingly $12.1 \%$ of the participants were from the Social Sciences faculty and also the remaining $12.1 \%$ of them belonged to the Management and Commerce faculty. $40.3 \%$ of the participants were in the third year of their study, $31.7 \%$ and $28.0 \%$ of them were in the second and first years respectively. As for the qualitative strand of the research, the youngest among the members of the SRC was 24 years old while the oldest was 33 years old. The departments of the five of them cut across faculties of law, management, humanities, and social sciences, see Table 2. In South Africa, undergraduate degree programs take a minimum of 3 years and 5 years maximum. For instance, undergraduate degrees in commerce, communication, public administration, and human movement science are studied for 3 years while others such as nursing, law, agricultural extension programs take a minimum of 4 or 5 years depending on the requirements for admission. It is also imperative to reiterate that all participants in this study are undergraduate students at one of the historically black universities in the Eastern Cape Province, South Africa. 
Badaru, K. A. \& Adu, E. O., The Political Awareness and Participation of University Students in post-Apartheid South Africa

Table 1. Students' Socio-Demographic Characteristics

\begin{tabular}{|c|c|c|}
\hline Variables & Frequency & Percentage (\%) \\
\hline \multicolumn{3}{|l|}{ Sex } \\
\hline Male & 225 & 60.5 \\
\hline Female & 147 & 39.5 \\
\hline \multicolumn{3}{|l|}{ Age } \\
\hline 16-20years & 78 & 21.0 \\
\hline 21-25years & 152 & 41.0 \\
\hline 26-30years & 127 & 34.2 \\
\hline 31 and above & 14 & 3.8 \\
\hline \multicolumn{3}{|l|}{ Faculty/Department } \\
\hline Education & 36 & 9.7 \\
\hline \multicolumn{3}{|l|}{ Political Science/ } \\
\hline Public Administration & 89 & 21.5 \\
\hline Sciences & 135 & 36.3 \\
\hline $\begin{array}{l}\text { Social Sciences and } \\
\text { Humanities }\end{array}$ & 45 & 12.1 \\
\hline $\begin{array}{l}\text { Management and } \\
\text { Commerce }\end{array}$ & 45 & 12.1 \\
\hline Law & 31 & 8.3 \\
\hline \multicolumn{3}{|l|}{ Year of Study } \\
\hline Year one & 104 & 28.0 \\
\hline Year two & 118 & 31.7 \\
\hline Year three & 150 & 40.3 \\
\hline
\end{tabular}

Table 2. Interview Participants' Profiles

\begin{tabular}{lllcc}
\hline Participants & Department & Sex & Age & $\begin{array}{c}\text { Number of } \\
\text { terms in office }\end{array}$ \\
\hline Interviewee 1 & Applied Communication & Male & 31 & 2 \\
& Management & Male & 24 & 2 \\
Interviewee 2 & Law & Male & 26 & 2 \\
Interviewee 3 & Public Administration & Male & 27 & 1 \\
Interviewee 4 & Economics & Female & 33 & 1 \\
Interviewee 5 & Accounting & &
\end{tabular}

As for the qualitative strand of the research, the youngest among the members of the SRC was 24 years old while the oldest was 33 years old. Four of them were males while one was a female. The departments of the five of them cut across management, humanities, and social sciences, see Table 2.

\section{Instruments for Data Collection}

Questionnaire: The principal instrument used for data collection in this study was a questionnaire which was complemented by a semi-structured interview and other relevant official documents such as the constitutions of student political organizations and the SRCs. The 
Badaru, K. A. \& Adu, E. O., The Political Awareness and Participation of University Students in post-Apartheid South Africa

political awareness of respondents was measured with 11 items and the Cronbach alpha coefficient yielded a value of 0.89 while their levels of political participation were determined by using 8 items for on-campus political activities (Coefficient value 0.78 ) and 6 other items for off-campus (Coefficient value 0.66). All of these coefficient values suggested that the instrument had a high level of reliability or internal consistency. A total of 450 copies of the research questionnaire were distributed but only 372 copies (82.7\%) were retrieved from the respondents for the final analysis. The participants cut across six faculties in the university. The questionnaires were distributed to the students personally by the principal researcher while he also conducted the interviews with the SRC members on a one-on-one staggered basis for a period of three months.

Interviews: Interviews were conducted with a validated guide by other researchers. We secured the consent of the participants for their views to be recorded using gargets such as the taperecorder and android phone's video camera. Verbatim transcriptions of both video and audio recordings were meticulously done and returned in form of texts to the participants to read and confirm that textual data were in tandem with their expressed opinions and narrations as collected during the fieldwork. After confirmation of the transcribed data, we coded and recoded the texts into different themes and sub-themes that were in tandem with the research questions. Lastly, an audit trail was carried out to ensure that results confirmed dependability.

\section{Validity and Reliability of the Data}

The researchers had to seek the opinions of experts to ensure the validity of the data collection instrument. It was further subjected to pilot testing by administering it to other participants, twenty in number, who did not eventually take part in the original study. The Cronbach alpha was employed to determine the coefficient value $(0.89)$ from the reliability test to which the instrument had been subjected.

\section{Data Trustworthiness}

Data trustworthiness is concerned with the need for the research findings to be considered worthy of being given attention (Graff, 2014). As provided by Lincoln and Guba (as cited in Loh, 2013), the criteria for establishing and ensuring the trustworthiness of data are credibility (internal validity), transferability (external validity), dependability (reliability), and conformability (objectivity). All of these criteria were meticulously considered while collecting the qualitative data for this study.

\section{Data Analysis}

The quantitative data were analyzed using simple descriptive and Pearson correlation statistics while the qualitative data were analyzed with the aid of the thematic content analysis. We utilized the IBM SPSS statistical package version 20 and the Atlas 6.2 software application for quantitative and qualitative analyses respectively.

\section{Ethical Considerations}

This study got approval from the researchers' institution of affiliation. Besides, we had to secure permission from the relevant authorities of the university where the study was conducted in the Eastern Cape Province of South Africa. Participants were also made to complete and sign 
Badaru, K. A. \& Adu, E. O., The Political Awareness and Participation of University Students in post-Apartheid South Africa

the informed consent forms in compliance with all ethical issues such as voluntary participation and confidentiality.

\section{Results}

In this study, the researchers investigated the participants' level of political awareness, various ways of their political engagements on and off the campus, and the extent to which their political awareness level is associated with their participation in politics.

\section{To what extent are university students politically aware in South Africa?}

Table 3. Level of Students' Political Awareness

\begin{tabular}{|c|c|c|c|c|}
\hline Items & $\begin{array}{l}\text { Extremely } \\
\text { Aware }\end{array}$ & $\begin{array}{l}\text { Moderatel } \\
\text { y Aware }\end{array}$ & $\begin{array}{l}\text { Somewhat } \\
\text { Aware }\end{array}$ & $\begin{array}{l}\text { Not at all } \\
\text { Aware }\end{array}$ \\
\hline $\begin{array}{l}\text { Are you aware of your rights to vote and be } \\
\text { voted for? }\end{array}$ & 245(65.9) & $102(27.4)$ & $18(4.8)$ & $7(1.9)$ \\
\hline Are you aware of your freedom expression? & 249(66.9) & $100(26.9)$ & $21(5.6)$ & $2(0.5)$ \\
\hline $\begin{array}{l}\text { Are you aware of the ideologies of South Africa's } \\
\text { political parties? }\end{array}$ & $65(17.5)$ & $192(51.6)$ & $103(27.7)$ & $12(3.2)$ \\
\hline $\begin{array}{l}\text { Are you aware of development of political } \\
\text { issues like the state capture? }\end{array}$ & $117(31.5)$ & $140(37.6)$ & $96(25.8)$ & 19(5.1) \\
\hline $\begin{array}{l}\text { Are you aware of the role of Government in a } \\
\text { democracy? }\end{array}$ & 186(50.0) & $137(36.8)$ & $46(12.4)$ & $3(0.8)$ \\
\hline $\begin{array}{l}\text { Are you aware of your obligations as a } \\
\text { citizen? }\end{array}$ & $157(42.2)$ & $151(40.6)$ & $42(11.3)$ & 22(5.9) \\
\hline Are you aware of your rights to fair hearing? & 139(37.4) & $159(42.7)$ & $55(14.8)$ & 19(5.1) \\
\hline $\begin{array}{l}\text { Are you aware of the role of the police in a } \\
\text { democracy? }\end{array}$ & $134(36.0)$ & $158(42.5)$ & $74(19.9)$ & $6(1.6)$ \\
\hline $\begin{array}{l}\text { Are you aware of the importance of the } \\
\text { parliament in a democracy? }\end{array}$ & $177(47.6)$ & $132(35.5)$ & $59(15.9)$ & $4(1.1)$ \\
\hline $\begin{array}{l}\text { Are you aware of the functions of your } \\
\text { municipality or local government council? }\end{array}$ & $117(31.5)$ & $168(45.2)$ & $70(18.8)$ & $17(4.6)$ \\
\hline $\begin{array}{l}\text { Are you aware of the importance of the } \\
\text { constitution in a democracy? }\end{array}$ & $186(50.0)$ & $130(34.9)$ & $53(14.2)$ & $3(0.8)$ \\
\hline
\end{tabular}

Table 3 above presents the students' level of political awareness. The students were asked questions relating to South African politics in terms of democracy, democratic institutions, and issues of citizenship rights, obligations, and duties as well as the importance of the constitution in the Republic of South Africa. Almost all participants (98.1\%) were aware of their rights to vote. Similarly, almost all the participants (99.4\%) were aware of their right to freedom of expression. In the same vein, almost all the students (96.8\%) were aware of the ideologies of South Africa's political parties. Interestingly, an overwhelming proportion of the participants 
Badaru, K. A. \& Adu, E. O., The Political Awareness and Participation of University Students in post-Apartheid South Africa

(94.9\%) were aware of political development such as state capture. It is equally amazing to find that virtually all the respondents (99.2\%) disclosed that they were aware of the role of government in a democracy. Moreover, a vast proportion of the students (94.1\%) were aware of their obligations as citizens. Finally, almost all the participants (99.1\%) were aware of the importance of parliament and the constitution in a democracy.

The general narratives of the SRC members indicated that they had some level of political awareness. One of them remarked as follows:

I believe that the level of my political awareness has encouraged me to become a part of the SRC leadership on campus. I have always loved to read and discuss politics with friends, family, and lecturers. As a South African, I have an idea of what my rights are which include voting during elections. Being politically aware is one thing, and another thing is to have the courage and strong will to join politics whether the university administration will be friendly with your decisions or demands...rights of the students must be respected. Our welfare should be important to any serious university manager or Vice-chancellor, but eh... [sic] you need a lot of courage to confront an undemocratic administration. So, if you don't have the courage, you will withdraw from participating because you don't want to be a scapegoat (A Public Administration male student, 26 years old).

\section{In what ways have students participated in politics on and off campus?}

Table 4. Students' Participation in the 2017 SRC Elections

\begin{tabular}{lcc}
\hline & \multicolumn{1}{c}{ Yes } & No \\
\hline Did you vote in the 2017 SRC election? & $183(49.2)$ & $189(50.8)$ \\
Were you actively involved in the 2017 SRC election campaigns? & $38(10.2)$ & $334(89.8)$ \\
Did you vote in the 2014 national election? & $113(30.4)$ & $259(69.6)$ \\
$\begin{array}{l}\text { Were you actively involved in the provincial and national election } \\
\text { campaign activities? }\end{array}$ & $48(12.9)$ & $324(87.1)$ \\
\hline
\end{tabular}

Results in Table 4 show that less than half (49.2\%) of the participants did vote during the 2017 SRC election. A majority (89.8\%) of them had never been involved in the SRC election campaigns. Similarly, most of them (69.6\%) did not vote during the 2014 national (general) elections while a significant proportion (87.1\%) did not have any involvement in the provincial and national campaign activities. 
Badaru, K. A. \& Adu, E. O., The Political Awareness and Participation of University Students in post-Apartheid South Africa

Table 5. Students' Activities in the University

\begin{tabular}{lll}
\hline Have you taken part in any of these activities in the university? & & \\
\hline & \multicolumn{1}{l}{ Yes } & No \\
Attended a political meeting of students (e.g. the mass meeting) & $144(39.6)$ & $220(60.4)$ \\
Contacted a senior official of the university like the VC to discuss issues or make & $50(13.4)$ & $322(86.6)$ \\
formal complaints about certain issues affecting students' affairs. & & \\
Wrote a letter to student leaders or made a leaflet to protest against issues. & $46(12.4)$ & $326(87.6)$ \\
Joined other students to stage a protest march on campus. & $79(21.2)$ & $293(78.8)$ \\
\hline
\end{tabular}

Table 5 shows the various activities which students had engaged in on the university campus. A majority of the participants never took part in the list of the political or politically-related activities as shown in the table 5 above. A majority of the participants (60.4\%) did not attend students' mass meetings. Similarly, the majority of the participants (86.6\%) did not contact any senior university official to discuss issues or make a formal complaint about issues affecting students' affairs. Similarly, only a small proportion (12.4\%) of the students wrote a letter to student leaders or made a leaflet to protest against specific issues of concern. Lastly, only $21.2 \%$ of the participants had ever joined other students for a protest march on campus.

From the SRC member's perspective, a narrative was noted as follows:

As a passionate citizen, I had the intention of serving in leadership positions once an opportunity presented itself. On securing admission to the university, I joined a political organization (PASMA), and I campaigned vigorously for our candidates in the SRC elections for that year 2016. I have always represented the organization on student affairs in meetings with the university officers and other party leaders at the provincial and national levels (An Economics male student, 27 years old).

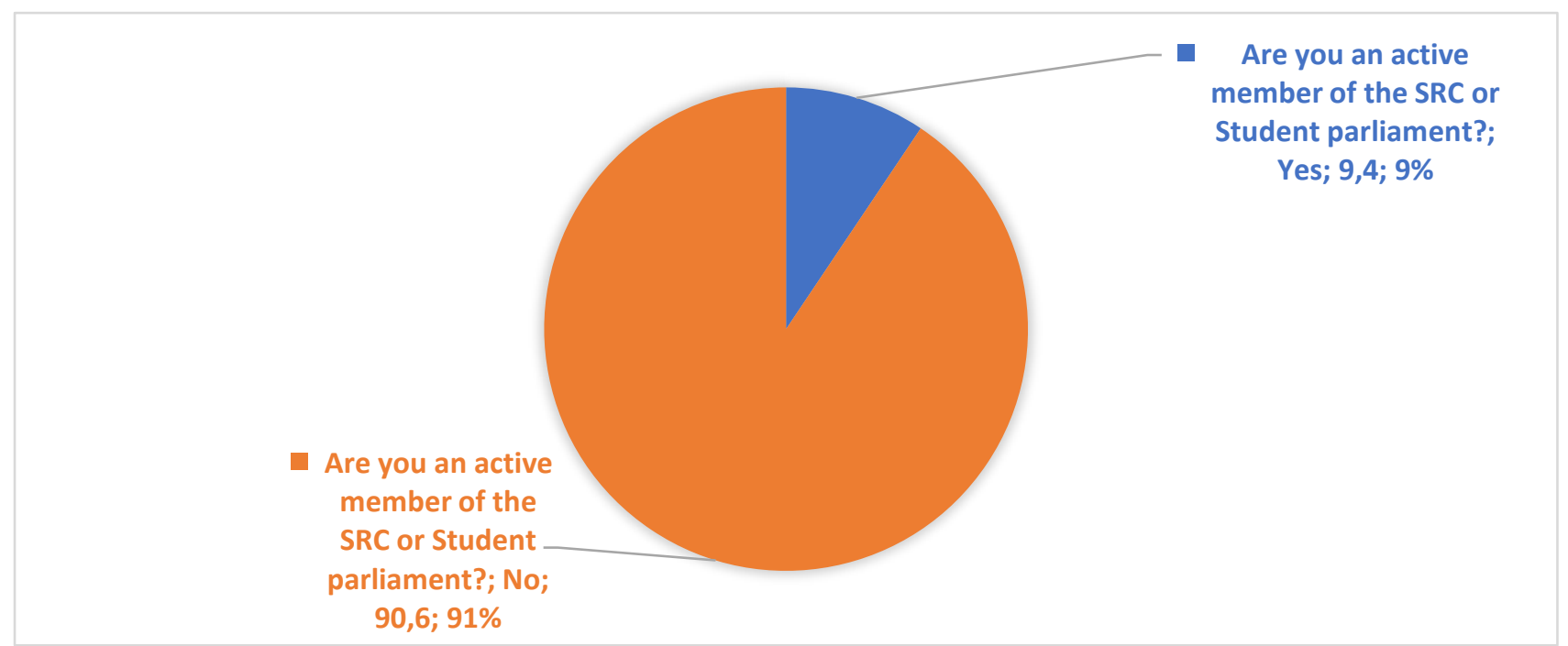

Fig. 1. Distribution of Participants into Active and Inactive Members of the SRC 
Badaru, K. A. \& Adu, E. O., The Political Awareness and Participation of University Students in post-Apartheid South Africa

Figure 1 indicates that less than 10\% of the participants were active members of the Student Representative Council (SRC) on campus while the rest of them (91\%) were not active members of the SRC.

Table 6. Students' Participation in National Political Activities

\begin{tabular}{llll}
\hline Did you take part in any of these activities in the past? & & \\
\hline & Yes & No \\
Attended a political party's gathering or meeting. & $144(39.6)$ & $220(60.4)$ \\
Contacted a government official to discuss or complain about issues. & $50(13.4)$ & $322(86.6)$ \\
Wrote a letter to a local/national newspaper about national issues. & $46(12.4)$ & $326(87.6)$ \\
Joined a national protest or demonstration against government. & $79(21.2)$ & $293(78.8)$ \\
Took part in the campaigns or rallies in support of a political party. & $113(30.4)$ & $259(69.6)$ \\
Joined in a debate on national issues at a political forum. & $53(14.2)$ & $319(85.8)$ \\
\hline
\end{tabular}

Table 6 presents the responses of the participants to a question which sought to find whether or not the participants did take part in certain activities outside the campus politics. A majority of the participants claimed not to have taken part in any of these activities. For instance, only $39.6 \%$ of the students affirmatively confirmed that they had attended a political party's gathering or meeting; $13.4 \%$ of the participants did contact a government official to discuss or complain about issues of national or local concern in South Africa. Another $12.4 \%$ of the students did write a regional/national newspaper about matters of national interests. In terms of participation in national protest or demonstration, only $21.2 \%$ did join in protesting against the government, while $30.4 \%$ of the students claimed to have taken part in the political parties' rallies or campaigns.

From the qualitative point of view, the SRC president of the university under investigation had this to say:

I am a member of SASCO, ANC Youth League, Young Communist League of South Africa. I was secretary of Young Communist League of South Africa. I set meetings with all political organizations. I was privileged to have meetings and speak with faculty management members, VC at the political level. I emerged as SRC president because I was first an activist becoming politician. In national politics, I started voting since 2004, voted in 2009 and 2014. I am currently a member of the ANC. I'm interested in becoming a politician at the provincial level in the position of the Member of Parliament (MP) in the future (An Applied Communication Management male student, 31 years old). 
Badaru, K. A. \& Adu, E. O., The Political Awareness and Participation of University Students in post-Apartheid South Africa

\section{To what extent is students' political awareness associated with their participation in politics?}

Table 7. Pearson Correlation Statistics Showing Relationship between Political Awareness and On-campus Political Participation

\begin{tabular}{lcl}
\hline Variable & Pearson Coefficient & P-Value \\
\hline Political awareness & 0.130 & 0.012 \\
Sex & -0.076 & 0.146 \\
Age & -0.048 & 0.360 \\
Faculty of study & 0.037 & 0.476 \\
\hline
\end{tabular}

The relationship between political awareness and on-campus political participation was examined using Pearson correlation statistics (Table 7). The result shows that political awareness was significantly correlated with political on-campus participation $(r=0.130)$ as indicated in Table 7.

Table 8. Ordinary Least Square Regression Showing Relationship between Political Awareness and On-campus Political Participation

\begin{tabular}{llllc}
\hline Variable & $\begin{array}{l}\text { Unstandardized } \\
\text { coefficient (B) }\end{array}$ & Standard error & $\begin{array}{l}\text { Standardized } \\
\text { coefficient (B) }\end{array}$ & $\begin{array}{c}p \text { - } \\
\text { value }\end{array}$ \\
\hline Constant & 2.14 & 0.54 & & 0.001 \\
Political awareness & 0.23 & 0.15 & 0.08 & 0.124 \\
\hline
\end{tabular}

The coefficient indicates that there is a weak positive association between political awareness and on-campus political participation. In the ordinary least squares' regression analysis, the relationship between political awareness and political on-campus involvement was not statistically significant (as shown in Table 8).

Table 9. Pearson Correlation Statistics Showing Relationship between Political Awareness and Off-Campus Political Participation

\begin{tabular}{lcc}
\hline Variable & Pearson Coefficient & P-value \\
\hline Political awareness & 0.185 & $<0.001$ \\
Sex & -0.077 & 0.144 \\
Age & 0.093 & 0.076 \\
Faculty of study & 0.021 & 0.685 \\
Year of study & 0.195 & $<0.001$ \\
\hline
\end{tabular}

The association between political awareness and off-campus political participation was examined with Pearson correlation statistics, and the result shows that there was a significant 
Badaru, K. A. \& Adu, E. O., The Political Awareness and Participation of University Students in post-Apartheid South Africa

positive relationship between political awareness and off-campus political participation $(r=$ $0.185)$, see Table 9.

Table 10. Ordinary Least Square Regression Showing Relationship between Political Awareness and Off-campus Political Participation

\begin{tabular}{lcccc}
\hline Variable & $\begin{array}{l}\text { Unstandardized } \\
\text { coefficient (B) }\end{array}$ & Standard error & $\begin{array}{l}\text { Standardized } \\
\text { coefficient (B) }\end{array}$ & $p$-value \\
\hline Constant & 0.074 & 0.789 & & \\
Political awareness & 0.076 & 0.022 & 0.178 & 0.001 \\
\hline
\end{tabular}

In the ordinary least squares' regression analysis, the relationship between political awareness and off-campus political participation was statistically significant (Table 10).

\section{Discussion}

\section{To what extent are university students politically aware in post-apartheid South Africa?}

The first question guiding our discussion of findings in this study was to ascertain the extent of the university students 'political awareness. This study has revealed that the level of political awareness of the participants was high. They demonstrated an understanding of the political system, political developments, and politically related issues in South Africa. Alsati and AlGhanem (2017) have argued that institutions of learning play a critical role in raising political awareness of persons through various pedagogical approaches, social and academic programs integrated as part of curricula, lectures, conferences, and training towards the preparation of individuals to take up responsibilities for public affairs and fulfillment of civic duties. Unarguably, this finding was not surprising at all as the students had unhindered access to all sorts of digital media for political information. On their campus, there is the provision of the internet and other digital technologies. This has given them opportunities to interact with online news media through which political information is related to them on a 24-hour basis. This is consistent with the findings of the studies conducted by Ahmed et al. (2015) and Ali et al. (2013). Their conclusions have corroborated this study's finding that students who are exposed to the use of media and forms of political education would exhibit some increased level of political awareness. From our observation, students sometimes go on YouTube channels to watch much of the news; talk shows on political issues, and exclusive live coverage of political events through the internet access made available to them on campus and through their mobile telephone technologies. The study conducted by Yaseen, Mamdani, and Siddiqui (2018) found that political talk shows through television and radio did help in increasing the political awareness levels among the university students. We, therefore, wanted to believe that the students' access to all forms of political education on their campus must have contributed to their high levels of political awareness as found out in this study.

Contrary to the belief that a high level of political awareness will engender an increase in political participation (Kuotsu 2016), we found that the students' political participation was relatively low in this study. However, this is in tandem with Robertson's argument that concerns have been raised in the literature about the low rates of young people's participation in political 
Badaru, K. A. \& Adu, E. O., The Political Awareness and Participation of University Students in post-Apartheid South Africa

activities (Robertson 2009). The rates of participation of university students in conventional politics such as voting and party membership are low across the globe. Fieldhouse et al. have argued that young people are least likely to participate in voting and activities of the political parties (Fieldhouse et al., 2007). The principal researcher in this study observed that students show more interest to participate in unconventional political activities such as protests than they participate in conventional politics. For example, the period of this study's fieldwork coincided with the period of the Student Representative Council (SRC) election of the university under investigation, and he was surprised to see student leaders knocking on the doors of students at the odd time about $21 \mathrm{~h} 00$ persuading those who had not voted to go out and do so. This was an election that ought to have ended at $15 \mathrm{~h} 00$ but had to be extended till late in the night to accommodate more students to cast their votes after persuasions from the various leaders of the participating student organizations in the election. This action of the student leaders could be likened to forcing an unwilling horse down to the riverside to drink water.

\section{In what ways have students participated in politics on and off-campus?}

This second question was raised in an attempt to articulate the discourses interweaving around various ways of students' participation in politics within and outside their campus. Regarding the campus politics, this study has found that almost half of the sampled university students actively participated and did vote in the SRC election that took place on campus in 2017 while a very small percentage of the participants were actively involved in the SRC electioneering campaigns of the same year. Another important finding was that a vast majority of the participants did not vote during the 2014 national election. Most of them also were not actively involved in the electioneering campaign activities both at the provincial and national levels. Within the university campus, a larger percentage of the students were not active members of either the SRC or student parliamentary body as represented in figure 1. This accounts for reasons why most of them declared that they never attended mass meetings (student political meetings), felt unconcerned about taking up issues of student welfare or complaints about issues affecting their welfare on campus with the university authorities, had no regard for staging protests along with their elected student leaders on issues affecting their wellbeing on the campus.

In the same vein, this study has specifically confirmed the general concerns (see Castillo et al., 2015; Fieldhouse et al., 2007) of low political participation of youth in conventional politics as most of the participants stated that they had never attended political meetings or gatherings, nor contacted any government officials to discuss issues of concerns that require political moves, and never joined in debating issues of national concerns at any political forum or campaign rallies. In contrast to the above, the SRC president that was one of the interview participants appeared to be more politically aware and was actively participating in politics at the campus level as well as at the provincial and national levels. Just as Adelabu and Akinsolu (2009) and Rou et al. (2017) have agreed that the SRC provides the platform as the first political organization where students of higher institutions practice political functions and actively participate in political activities. He claimed to an active member of the South African Students Congress (SASCO), ANCYL, Young Communist League of South Africa. More interestingly, he explicitly revealed that he had been privileged to have meetings with the faculty management members, and the Vice-chancellor even before he emerged as the SRC president. This is in 
Badaru, K. A. \& Adu, E. O., The Political Awareness and Participation of University Students in post-Apartheid South Africa

tandem with South Africa's provision for the inclusion of the SRCs in its higher education policy to promote cooperative governance philosophy among stakeholders in the nation's postapartheid higher education and training (Klemenčič et al., 2016). He was an activist. He stated further that he had been voting in the national and provincial elections since 2004. But, I probed further to know why he was so keenly interested in politics despite being a student of communication management. He responded that he wished to become a politician in the future and a member of parliament at the provincial or national level. While he was still an undergraduate student, he claimed to be a registered member of the ruling ANC. Both Nyundu et al. (2015) and Lake (2010) have identified success stories of prominent politicians and the need to have a sense of political belonging as factors propelling students' interests and participation in politics. In contrast, students' political apathy could be a result of their poor perception of political leaders, having fears not to lose their studentship, and other academic benefits from the university authorities.

\section{To what extent is students' political awareness associated with their participation in politics?}

Although students' level of political participation was generally assessed to be far below the average in this study, it was interestingly found that there was a significantly positive relationship between students' political awareness and their participation in both on-campus and off-campus politics. In confirmation of this finding, previous studies conducted by AlKhaza'leh and Lahiani (2021), Sarwar et al. (2021), and Kholisoh et al. (2019) have also found that there is a connection between political awareness and political participation. This was further corroborated by the finding in one Kenyan study conducted by Ndiritu stating that an increased level of political awareness among the youth had led to more participation in the political processes (Ndiritu 2007). Similarly, Amoateng (2015) found that students in a study exhibited a high level of political awareness and had a positive correlation with their participation in partisan activities. In this study, $49 \%$ of the participants had participated in voting in the year 2017 SRC election while 30\% voted during the 2014 national election. We may have to assume that the non-voting students had other reasons (not to be considered in this study) for not participating in political activities both at the campus and national levels. However, this study has so far established that political awareness is a desideratum for increasing, and to a large extent has a correlation with, levels of participation in political activities off and on-campus.

\section{Implications of the Findings}

The findings of this study have practical implications for the university administrators, government, and educators. The university administrators have to devise the means of redirecting the energies and political enthusiasm of their students towards conventional democratic practices as against their usual acts of rioting and demonstrations when they feel aggrieved. This implies that reasonable demands from students on any critical issues should be looked into without violating their democratic rights. The government needs to expand the political education curriculum for university students to adequately address and emphasize the importance of participation in the democratic processes. By so doing, the universities would become alive to their responsibilities of building in their students the political consciousness for their involvement in the country's democracy. Finally, the implication for the educators is 
Badaru, K. A. \& Adu, E. O., The Political Awareness and Participation of University Students in post-Apartheid South Africa

the need for them to conduct more specific studies on the students' political awareness and participation across other provinces in South Africa. They also have the responsibility of consciously encouraging their students to become much more interested in political activities in higher education institutions and at the national level, to say the least.

\section{Conclusion}

This paper was an attempt to make intellectual and scholarly inputs into the body of literature on the role of political awareness towards participation in partisan activities. We have highlighted the various arguments of scholars on the significance of political awareness to raise the level of participation of the citizens in a democracy. Besides, we have made arguments to support the fact that university students are the future leaders for the continuation of the nation's democratic politics. South Africa, therefore, cannot afford to lose a significant proportion of its population (the youth) to political apathy and disenchantment with participation. Hence, it became critical to conduct this research to be able to ascertain the level of university students' political awareness and participation in politics.

Be that as it may, three key findings have emerged from this study. Firstly, the university students were found to have a high level of political awareness. This is good for the democratic development of the country because only the citizens who are politically aware would be interested in demanding accountability and good governance from their elected officials. They are also capable of contributing to the democratic processes through voting and regular engagements with the government or its representatives. Secondly, we found that participation of the students in conventional politics such as voting was relatively low compared with their high levels of political awareness. This kind of situation has to be given attention by the government, civil society groups, and other stakeholders in the project of building democracy in post-apartheid South Africa. Thirdly, we have also established that political awareness levels are positively associated with levels of political participation. It is, therefore, imperative for the citizens' levels of political awareness to be channeled towards improving the rates of their participation in the political processes to advance further growth in the country's democratic practices.

\section{Acknowledgement}

We are appreciative of the financial support received from our institution's Govan Mbeki Research and Development Centre (GMRDC) in South Africa that helped us in the course of carrying out this study. We also acknowledge the contributions of participants, colleagues (most especially, Anthony Ajayi), and the anonymous reviewers in shaping and reshaping the final draft of this article. 
Badaru, K. A. \& Adu, E. O., The Political Awareness and Participation of University Students in post-Apartheid South Africa

\section{References}

Adelabu, M. A., \& Akinsolu, A. O. (2009). Political education through the university: A survey of Nigerian university students. African journal of political science and international relations, 3(2), 046-053.

Ahmed, Z., Muhammad, A. J., Muhammad, M., Nida, F., Tahir, H., \& Subcampus, A. (2015). Comparing the Level of Political Awareness among the Students of Social and Natural Sciences: A Case Study of Public Sector Universities in Pakistan. Life, 13 (2): 64-67.

Ali, A., Sohail, S., \& Hassan, S. A. (2013). Political awareness and media's consumption patterns among students: A Case Study of University of Gujrat, Pakistan. International Journal of Research in Social Sciences, 3(4): 523-34.

Al-Khaza'leh, M. S., \& Lahiani, H. (2021). University and Political Awareness among Students: A Study in the Role of University in Promoting Political Awareness. Journal of Educational and Social Research, 11(2), 204-204. https://doi.org/10.36941/jesr-20210041

Alsati, A. S. M., \& Abd ulmutallab Ghanem, A. S. (2017). The Political Knowledge of University Students (A Comparative Study between Jordan and Libya). Asian Social Science, 13(11).

Althubetat, Q., \& Jarrar, A. (2013). The Impact of teaching political science on political awareness of Petra University students: A Jordanian case. Research on Humanities and Social Sciences, 3(6), 112-121.

Amechi, O. R., Innocent, E. O., \& Ikechukwu, A. (2018). Political education in Nigeria: the mobilisation theory thesis perspective. Art Human Open Acc J, 2(5), 246-256.

Amoateng, A. (2015). The End of Politics by the Youth? Higher Education, Youth Identity and Recession of Political Participation by South Africa's 'Born-Frees': 1 The Case of Undergraduate Students at a Public University. International Journal of African Renaissance Studies-Multi-, Inter-and Transdisciplinarity, 10(1): 102-119.

Anwar, M., \& Jan, M. (2010). Role of Media in Political Socialization: The Case of Pakistan. Dialogue (Pakistan), 5(3).

https://www.qurtuba.edu.pk/thedialogue/The\%20Dialogue/5 3/Dialogue July Septe mber2010 212-227.pdf?xldxuojagkuvqezw

Badaru, K. A., \& Adu, E. O. (2020). University students' media use and political participation in South Africa. South African Journal of Higher Education, 34(1), 18-36. http://dx.doi.org/10.20853/34-1-3382

Castillo, J. C., Miranda, D., Bonhomme, M., Cox, C., \& Bascopé, M. (2015). Mitigating the political participation gap from the school: the roles of civic knowledge and classroom climate. Journal of Youth Studies, 18(1), 16-35. http://dx.doi.org/10.1080/13676261.2014.933199

Dibetle, M. (2007, June 14). Student Politics is Dead. Mail and Guardian, 14 June 2007. Available at: http://mg.co.za/article/2007-06-14-student-politics-is-dead. Retrieved on 4th March 2018.

Etikan, I., Musa, S. A., \& Alkassim, R. S. (2016). Comparison of convenience sampling and purposive sampling. American Journal of Theoretical and Applied Statistics, 5(1), 1-4. 
Badaru, K. A. \& Adu, E. O., The Political Awareness and Participation of University Students in post-Apartheid South Africa

Fieldhouse, E., Tranmer, M., \& Russell, A. (2007). Something about young people or something about elections? Electoral participation of young people in Europe: Evidence from a multilevel analysis of the European Social Survey. European journal of political research, 46(6), 797-822.

Frateschi, Y. (2016). Social participation for the democratization of democracy. DoisPontos, 13(2). http://dx.doi.org/10.5380/dp.v13i2.43124

Graff, J.C. (2014). Mixed methods research. In Evidence-based practice: an integrative approach to research, administration and Practice edited by H.R. Hall and L. A. Roussel, 45-64. Burlington, MA: Jones \& Bartlett Learning.

Gutmann, A. (1987). Democratic Education. Princeton, New Jersey: Princeton University Press.

Kholisoh, N., Yuliawati, E., Suci, N. R., \& Suharman, T. (2019). The influence of political messages in new media to political awareness and its impact on the political participation of millennial generation. Jurnal Komunikasi Ikatan Sarjana Komunikasi Indonesia, 4(2), 128-139.

Klemenčič, M., Luescher, T. M., \& Mugume, T. (2016). Student Organising in African Higher Education: Polity, Politics and Policies. Student politics in Africa: Representation and activism, 2, 9-26.

Kuotsu, K. (2016). Political Awareness and Its Impact in Political Participation: A Gender Study in Nagaland, India. International Journal of Innovative Research and Development, 5(8), 190-197.

Lake, M. (2010). Faith in crisis: Christian university students in peace and war. Australian Journal of Politics and History, 56(3), 441-454.

Loh, J. (2013). Inquiry into issues of trustworthiness and quality in narrative studies: A perspective. The qualitative report, 18(33), 1-15. Retrieved from http://www.nova.edu/ssss/QR/QR18/loh65.pdf

Luescher-Mamashela, T. M., Luescher, T. M., \& Kiiru, S. (2011). The University in Africa and Democratic Citizenship: Hothouse or Training Ground?: Report on Student Surveys Conducted at the University of Nairobi, Kenya, the University of Cape Town, South Africa, and the University of Dar Es Salaam, Tanzania. African Minds.

Mhlomi, Y., \& Osunkunle, O. (2017). Social media and youth political participation in South Africa's 2014 general election. Communitas, 22, 149-158.

Moreku, C. (2014). The involvement and participation of student representative councils in cooperative governance in higher education institutions in South Africa (Doctoral dissertation, Welkom: Central University of Technology, Free State).

Miller, D. (1992). Deliberative democracy and social choice. In D. Held (ed.), Prospects for democracy: North, South, East, West. Oxford: Polity Press.

Ndiritu, G. W. (2007). The role of television in creating political awareness among the youth. PhD diss., School of Journalism, University of Nairobi. [cited 24/01/2019]; Available from erepository.uonbi.ac.ke/handle/11295/20032

Nyundu, T., Naidoo, K., \& Chagonda, T. (2015). 'Getting involved on campus': student identities, student politics, and perceptions of the Student Representative Council (SRC). Journal of Sociology and Social Anthropology, 6(1), 149-161.

Resnick, D. \& Thurlow, J. (2015). African youth and persistence of marginalisation: Employment, politics, and prospects for change. New York: Routledge. 
Badaru, K. A. \& Adu, E. O., The Political Awareness and Participation of University Students in post-Apartheid South Africa

Republic of South Africa. (1997). The Higher Education Act. Act 101 of 1997.

Robertson, F. M. (2009). A study of youth political participation in Poland and Romania. PhD diss., UCL (University College London). https://discovery.ucl.ac.uk/id/eprint/18725/1/18725.pdf

Rou, C. J., Musa, D., \& Kamis, N. C. (2017). Students' Awareness towards the Student Representative Council: A Survey Conducted at Northern Region Polytechnics of Malaysia. Advanced Journal of Technical and Vocational Education, 1(2): 14-22.

Sarwar, M. S., Ramazan, T., \& Shafiq, J. (2021). Television and Political Awareness: Measuring the Impact of Political Talk Shows on Political Participation of Students of Lahore. Journal of Media Studies, 36(1), 217-233.

http://journals.pu.edu.pk/journals/index.php/jms/index

Sasikala, V., \& Francisca, S. (2017). Does Location Difference Determines Political Awareness? International Journal of Advance Research, Ideas and Innovations in Technology, 3(2), 78-81.

Sharma, B. M., \& Choudhary, M. (2014). A study of political awareness among senior secondary school students. Eduved International Journal of Interdisciplinary Research. Retrieved www. eduved. org/oct2014/editedJ0244. pdf on February, 11, 2019.

Teorell, J. (2006). Political participation and three theories of democracy: A research inventory and agenda. European Journal of Political Research, 45(5), 787-810.

Van Deth, J. W. (2001). Studying political participation: Towards a theory of everything. In joint sessions of workshops of the European consortium for political research, Grenoble, pp.1-19. Retrieved 18/03/2019 from https://ecpr.eu/filestore/paperproposal/c8b57aab-51d9-4aca-b65d-4510ccfc19a3.pdf

Verba, S., \& Nie, N.H. (1972). Participation in America: Political Democracy and Social Equality. New York: Harper and Row.

Yaseen, M., Mamdani, K. F., \& Siddiqui, M. (2018). The role of political talk shows in raising political awareness among youth: A case study of University of Karachi. International Journal of Humanities and Cultural Studies (IJHCS), 5(3), 90-108. 